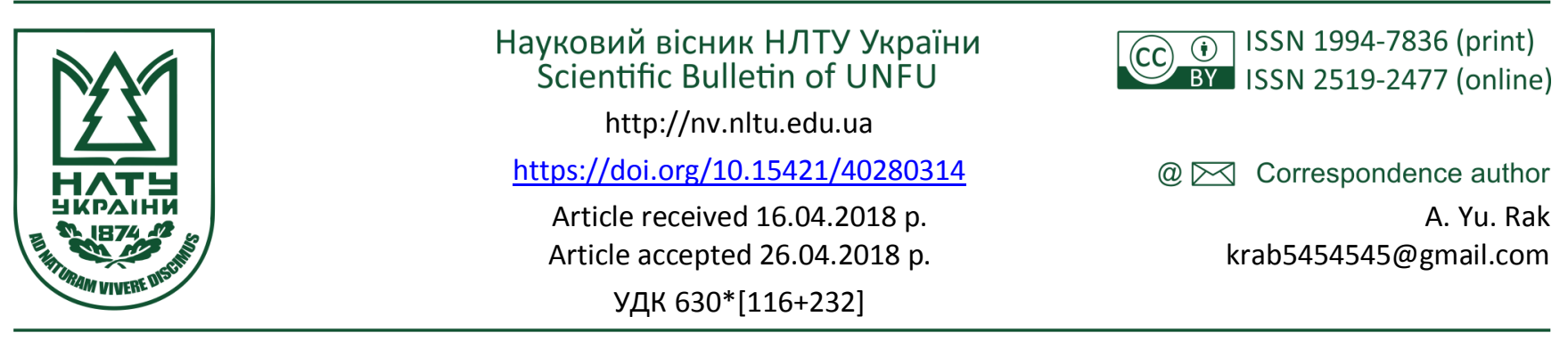

А. Ю. Рак

Прикарпатський національний університет ім. Василя Стефаника, м. Івано-Франківськ, Украйна

\title{
ВЗАЄМОЗВ'ЯЗОК І ВЗАЄМОЗУМОВЛЕНІСТЬ ПРОЯВУ СТИХІЙНИХ ЯВИЩ У ГІРСЬКО-ЛІСОВИХ ЕКОСИСТЕМАХ
}

Розглянуто взаємозв'язки та взаємовпливи між стихійними явищами у гірсько-лісових екосистемах Карпат - паводками, ерозією грунту, селями, зсувами, вітровалами, сніголамами, сходженням снігових лавин, періодичними засухами, лісовими пожежами та іншими. Наведено перелік стихійних явищ, які, взаємодіючи між собою, підсилюють окремі 3 них, уповільнюючи цим самим інші. З'ясовано, що внаслідок антропогенних змін лісових формацій інтенсифікувалися шкідливі процеси, знизилася продуктивність і стійкість лісових насаджень. Проаналізовано причини виникнення окремих видів стихійних явищ, їх вплив на лісові насадження в нинішній час і в перспективний період. Відзначено значну шкідливість для лісового господарства перманентних вітровалів. Наголошено на збитковості для лісових екосистем катастрофічних сніголамів і сніговалів, які деформують деревину, знижують їі приріст за висотою і запасом, та $є$ осередками виникнення грибкових захворювань. Зазначено, що у місцях стихійних явищ зростає небезпека лісових пожеж, знижується естетична і рекреаційна цінність лісових ландшафтів. Наведено перелік заходів, що послаблюють дію негативних природних стихійних явищ та підвищують стійкість лісових екосистем до антропогенного фактору. Важливим є твердження, що вітростійкість насаджень залежить від їх породного складу. Найбільш вітростійкими є насадження за участі ялиці білої та листяних порід.

Ключові слова: насадження; вітровали; паводки; лавини; сніголами; селі; грибні захворювання.

Вступ. Головним напрямом сучасного лісогосподарського виробництва в Україні є забезпечення сталого розвитку галузі. Він спрямований на більш повне задоволення потреб національного господарства і населення країни в різноманітній продукції лісового господарства.

Сталий розвиток забезпечить підвищення ефективності функціонування галузі за комплексного використання потенціалу лісосировинних ресурсів. Ключовою ланкою раціонального лісокористування і сталого розвитку лісового господарства України є екологізація лісогосподарської діяльності. Основні напрями ведення лісового господарства мають бути орієнтовані на збільшення лісистості території до оптимальної в усіх її природних зонах; збереження біологічного різноманіття лісових екосистем; підвищення стійкості лісових екосистем до негативних чинників середовища (Samoplavskyi, 2002).

Проблема стійкості лісових насаджень є однією 3 найактуальніших у лісовому господарстві. Вона залежить від багатьох причин, серед яких визначальними $\epsilon$ кліматичні, едафічні та антропогенні фактори. Антропогенний вплив на лісові екосистеми проявляється через господарську діяльність. Значний негативний вплив на величину лісового природно-ресурсного потенціалу карпатського регіону мають часті стихійні явища, які знижують стійкість і продуктивність екосистем загалом. Тому вивчення трансформаційних змін, як з наукових, так і прикладних позицій, що про- ходять у лісових насадженнях під їх впливом, є актуальним. Передусім це стосується наслідків паводків, ерозії грунтів, селевих і зсувних процесів, вітровалів, сніголамів, сходження снігових лавин, періодичних засух та лісових пожеж.

Активізації виникнення стихійних явищ у гірських лісових екосистемах сприяють також і особливості рельєфу, потужність грунтового покриву, структура рослинного покриву та його антропогенні зміни. Вплив рельєфу у гірських лісових екосистемах проявляється через крутизну й експозицію схилів та висоту н.р.м. Порівняно 3 кліматичними факторами елементи рельєфу характеризуються відносною постійністю.

Стихійні явища виникають через напруженість в екосистемах внаслідок дії на них природних і антропогенних чинників, що зумовлює порушення складних міжкомпонентних зв'язків і нетипових геофізичних процесів. Серед різних за природою чинників, дія яких активізує такі стихійні явища, завжди можна виділити провідні та похідні.

Мета роботи - з'ясувати вплив різних чинників на стихійні явища у гірських лісових екосистемах та опрацювати заходи щодо зменшення їх шкідливих наслідків.

Результати дослідження. Екологічні умови Карпат забезпечують високі прирости деревини. Однак, складна орографія у поєднанні з непередбачуваною метеорологічною ситуацією зумовлюють систематичний прояв вітровалів лісу, які завдають величезної шкоди лісовому господарству.

\section{Інформація про автора:}

Рак Андрій Юрійович, аспірант. Email: krab5454545@gmail.com

Цитування за ДСТУ: Рак А. Ю. Взаємозв'язок та взаємозумовленість прояву стихійних явищ у гірсько-лісових екосистемах. Науковий вісник НЛТУ України. 2018, т. 28, № 3. С. 67-72.

Citation APA: Rak, A. Yu. (2018). Interrelation and Interconditionality of the Emergence of Natural Phenomena in Mountain-Forest Ecosystems. Scientific Bulletin of UNFU, 28(3), 67-72. https://doi.org/10.15421/40280314 
Відомо, що у комплексі природних чинників виникнення вітровалів, основний є вітровий режим місцевості. Цей метеорологічний чинник природи глобально не залежить від людини, але в локальному аспекті окремі види господарської діяльності можуть певною мірою змінити характер та інтенсивність його прояву. Збитки, що пов'язані з вітровалами, величезні: втрата цінної деревини, поширення хвороб і шкідників у сусідніх деревостанах, зниження водоохоронних і водорегулювальних функцій лісу, посилення ерозійних процесів, додаткові витрати на відновлення пошкоджених вітровалами деревостанів та ін.

Статистичний облік періодичності вітровалів і вітроломів у Карпатах не доскональний і не повний. Практично вітровали більшої або меншої інтенсивності відбуваються щорічно (Hensiruk, 1971, 1971: Herushynskyi, 1995). Але вони не завжди фіксуються і потрапляють у відповідну звітність і джерела інформації. Досить часто ділянки із вітровалами незначної інтенсивності відводять під суцільні санітарні рубки і випадають з обліку як вітровали. Тільки вітровали дуже значного розміру за площею і великим об'ємом пошкодженої деревини фіксують в офіційних документах і вивчають тією чи іншою мірою. Інтенсивність вітровалів в окремі періоди сягає катастрофічних значень.

У літературних джерелах зосереджено увагу на низку чинників кліматичної, лісобіологічної, едафічної та орографічної природи, які беруть участь у формуванні вітровалонебезпечних ситуацій, зменшуючи або збільшуючи вітровалостійкість деревостанів. Серед них вагома роль належить вітровому режиму, опадам, породному складу деревостанів, їх віку, повноті, особливостям грунтових умов, крутизні та експозиції і висоті схилів.

Вітростійкість насаджень залежить від їх складу. Вважають, що найменш стійкою до дії вітру є ялина звичайна. Ялиця біла і листяні породи належать до деревних порід більшої вітростійкості. Раніше букові ліси займали 680 тис. га, а сьогодні - тільки 272 тис. га (зменшення на 60 \%). Площа ялицевих лісів скоротилася від 118 до 82 тис. га, тобто на 30 \%. Площа ялинових лісів збільшилася від 393 до 691 тис. га або у 2,5 раза. Отже, ялина стала панівною лісотвірною породою Карпат, яка послаблює вітростійкість лісів регіону загалом (Holubets, 1978).

На цей час сформувалися дві якісно різні за вітростійкістю зони ялинових лісів: зона природних і зона штучних ялинових лісів. Вітростійкість природних ялинників значно вища. Вважають, що найбільше пошкоджуються вітровалами деревостани старшого віку 80-90 років (Kysylevskyi - Babinin, Diakov, 1968). Найменш стійкими до вітрів $\epsilon$ насадження 3 повнотою 0,1-0,4, більш витривалі до них деревостани 3 повнотою 0,5-0,7, а найбільш вітростійкими є деревостани 3 повнотою 0,8-1,0 (Ivaniuk, 1996). Відзначено також, що iз зниженням класу бонітету від I до V індекс вітровалонебезпечності деревостанів збільшується. Серед орографічних чинників найбільший вплив на формування вітровалонебезпечних ситуацій має висота розміщення місцевості н.р.м. й експозиції схилів (Ivaniuk, 1996: Prokh, 1972, 1974).

Фактор антропогенного впливу на лісовий покрив Карпат поступово перетворився 3 малопомітного неістотного за інтенсивністю дії на потужний постійно ді- ючий, і широкомасштабний за територією. Він став рівнозначним $з$ іншими природними факторами, що у комплексі зумовлюють закономірності формування лісових асоціацій, циклічність у змінах стану рослинного покриття, ступінь вітровалостійкості деревостанів. Отже, сучасне лісове покриття потрібно розглядати як таке, що сформувалось за участі антропогенного фактора, тобто під впливом господарської діяльності людини (Kalutskyi, 1998)

Головним чинником, що сприяє утворенню таких стихійних явищ, як паводки, селі, лавини, зсуви та сніголами, є інтенсивні опади у вигляді дощу і снігу. Зливи - основна причина раптових і небезпечних паводків, що завдають значної шкоди природним комплексам і національному господарству загалом. Під час паводків затоплюються населені пункти, розмиваються і замулюються сільськогосподарські угіддя, руйнуються шляхи сполучення, лінії зв'язку, часто бувають і людські жертви. У 60-80-х роках ХХ ст. щорічні збитки від паводків становили близько 38 млн крб, сягаючи в окремі роки до 260 млн крб. Упродовж останніх десятиліть надзвичайно руйнівними були дощові й талодощові повені на Закарпатті в листопаді 1998 р. і березні 2001 р. та зливовий паводок у прикарпатських областях у липні 2008 р., які завдали матеріальної шкоди на суму понад 4 млрд грн (Oliinyk, 2013).

Особливо небезпечний підйом рівня вод у річках $\mathrm{i}$ потоках під час танення снігу, яке супроводжується значними опадами, а в літні періоди - під час проходження над Карпатами середземноморських циклонів. У такі дні в горах випадає надмірна кількість опадів. Через формування поверхневого стоку на крутих схилах надлишок води швидко надходить у гірські долини, де утворюються небезпечні паводки. Швидкість підняття рівня води в гідромережі та масштаби розливів гірських рік залежать від ценотичної структури, характеру і стану рослинного покриву на схилах водозбірних басейнів. Захисні функції рослинного покриву проявляються у високій водопоглинальній здатності біогеоценозів (Holubets, 1993). Вона неоднакова для різних типів рослинності. На ці процеси впливає крутизна схилів та інтенсивності опадів (Stoiko, Tretiak, 1993)

Інтегральним показником гідрологічної ролі лісу $є$ ступінь його впливу на формування режиму річкового стоку. Тому під час оцінювання гідрологічної ролі лісу для річкових басейнів (Oliinyk, 2007) пропонують передусім враховувати провідні фактори водного режиму гірської території - атмосферні опади, висотне розміщення водозборів та розмір їх площ. Як основний показник поглинальної здатності лісового покриву на таких водозбірних басейнах рекомендують приймати відсоток лісистості, а показники його ефективності - зменшення максимального стоку води під час паводків та збільшення меженного стоку в сухі сезони року, а також зростання річного об'єму грунтового живлення за рік. Загалом найважливішим чинником водного режиму та гідрологічної ролі лісу є метеорологічні умови, які безпосередньо впливають на формування стоку води і сумарне випаровування. На їх розподіл у гірських умовах впливає висота н.р.м., експозиція та орографія гірських хребтів.

Антропогенні зміни рослинності впливають на інтенсифікацію весняного танення снігу, що часто призводить до утворення небезпечних повеней. Як відомо, у 
зимові місяці відбувається нагромадження снігозапасів, які досягають своїх максимальних значень у кінці лютого. На їх величину істотно впливають висота та експозиція схилів, зимові відлиги, а також лісовий покрив. У Карпатах найбільші запаси води в снігу можуть сягати 400-500 мм (Kyryliuk, 1985). Сніготанення на висотах до 900 м н. р. м. відбувається в березні та квітні, а на вищих висотах - і в травні. Добре регулюють процеси нагромадження й танення снігу ялинові деревостани і слабо - букові (Oliinyk, 2013).

Значної шкоди лісовим екосистемам Карпат спричиняють катастрофічні сніголами. Вони знижують приріст деревини у висоту і за масою та деформують їх. Пошкоджені й фізіологічно ослаблені дерева $є$ осередками виникнення грибкових захворювань. У місцях масових сніголамів зростає небезпека лісових пожеж, знижується естетична й рекреаційна цінність лісових ландшафтів. Вважають (Holubets, 1993), що найбільша небезпека пошкоджень спостерігається у долинах гірських річок та середньогір'ї, де в теплішому кліматі і в багатих типах лісу ялина утворює крихку деревину. Небезпечні також навітряні й круті схили, на яких вона формує асиметричні крони. Щодо біологічних чинників, то під час вивчення причин виникнення сніголамів потрібно зважати на морфологічні й анатомічні особливості деревних порід. Особливо такі як форма крони та механічні властивості деревини. У Карпатах сніголами та сніговали періодично повторюються.

Снігові лавини виникають унаслідок взаємодії низки взаємопов'язаних природних чинників та антропогенного впливу на структуру природних екосистем. Лавинні процеси формуються на безлісних крутих схилах, iз накопиченим на схилах потужним сніговим покривом.

Під час сходження снігові лавини часто здирають не тільки чагарникову й трав'яну рослинність, а й грунтовий шар, гірські породи і лісові насадження. Для підвищення стійкості високогірних екосистем до лавинонебезпечних ситуацій потрібно підвищувати снігорегулювальну функцію деревно-чагарникової рослинності високогір'я, також iї здатність надійно фіксувати снігові маси в лавинозборах (Holubets, 1993).

Значних збитків лісовим екосистемам завдають селі - тимчасові потоки, які рухаються по водотоках, і характеризуються високим вмістом твердоуламкового матеріалу. Залежно від складу селевої маси, вмісту твердого матеріалу, структури потоку і його транспортувальної здатності розрізняють мулокам'яні, водокам'яні та інші типи селевих потоків. Серед природних чинників, які зумовлюють селеві явища у Карпатах, виділяють: велику розчленованість басейнів гірських річок, значне поглиблення русел, наявність крутих схилів, слабку денудаційну стійкість флішових товщ, значну потужність пухкого матеріалу на схилах гір, поширення безлісних площ, великий поверхневий стік. Провідне значення у формуванні селів відіграє транспортний процес, на який припадає 65 \% усіх випадків селеутворення (Bibliuk, 2008).

Головною причиною виникнення селів $є$ змиви $\mathrm{i}$ нагромадження уламкового матеріалу, після суцільних рубок попереднього періоду або ж під впливом інших антропогенних чинників (Perekhrest, 1971). Найбільше вони проявлялися у місцях проведення суцільних рубок у Карпатах у післявоєнні роки, і були приурочені до стрімких та обвально-осипних схилів (30-40), а також до вітровальних ділянок, зумовлених розташуванням лісосік.

Зсувні процеси грунтів найбільше поширені у гірських долинах Карпат, а також у Солотвинській улоговині (Закарпаття). Вони руйнують лісові насадження і завдають великої шкоди автомобільним дорогам та іншим спорудам. Великий вплив на них мають кліматичні чинники, передусім атмосферні опади та сейсмічна активність. Особливо сприяють цьому сильні зливи, які охоплюють великі території. Іншими чинниками сприяння зсувам $є$ суцільні рубки лісу на гірських схилах та будівництво лісовозних доріг, що підрізають схили і поширюють їх природну рівновагу (Bibliuk, 2003).

Серед стихійних явищ за останні десятиліття поширене масове всихання ялинників в Карпатах, яке проявляється на схилах всіх експозицій та в лісостанах різного віку. У процесах деградації та всихання ялинників важлива роль належить глобальному потеплінню, що призводить до зміни лісівничо-екологічних умов, а також складу та розвитку рослинного покриву.

Окрім змін клімату, всихання ялинових насаджень не зумовлюються низкою комплексних чинників антропогенного та абіотичного характеру. В умовах Українських Карпат цьому значною мірою сприяли: неправильне ведення лісового господарства в минулому; зміна мішаних корінних деревостанів на чисті ялинові; виконання лісовідновних і лісогосподарських робіт без врахування санітарного стану ділянок; випасання худоби; недотримання профілактичних заходів, спрямованих на запобігання поширенню збудників хвороб (Debryniuk, 2011).

Серед чинників, які становлять загрозу ялиновим лісам Карпат, можна також виділити підвищення температури повітря і поверхні грунту. Пересушування верхніх горизонтів грунту (в яких розташована поверхнева коренева система ялини) призводить до зниження біологічної стійкості ялинників і здатності протидіяти негативним біотичним чинникам (проникненню патогенних грибів та заселенню дерев комахами-фітофагами).

Зростання кількості посушливих днів та нагромадження значної кількості сухостійної деревини в ялинниках може бути причиною зростання частоти та інтенсивності лісових пожеж, що особливо небезпечно для віддалених важкодоступних районів регіону. Пожежі знищують лісову фауну і флору, лісову підстилку та зумовлюють деградацію грунтів, що ускладнює лісовідновлення на згарищах. Окрім цього, високі пірогенні температури негативно впливають на дерева, знижуючи їх життєздатність, наслідком чого $є$ їх ураження шкідниками та грибами.

Зміна структури лісових формацій призводить до зростання чисельності та збільшення площі із поширенням шкідників лісостанів. Для ялинників особливу небезпеку становить як поява нових небезпечних видів, так і зростання чисельності та розширення площі розселення звичних для цієї породи фітофагів. С дані (Isachenko, 2014) про просування на північ деяких потенційно небезпечних видів комах-філофагів, які пошкоджують асиміляційний апарат дерев (як листяних, так i хвойних), та зростання активності комах-ксилофагів. До хвоєгризних комах, які становлять загрозу для ялинових лісів Українських Карпат, можна віднести пиль- 
щиків із роду Cephalcia, спалахи масового розмноження яких періодично спостерігаються на території Західних Карпат.

Ялинники у передгір'ях Карпат, що створені штучно на місці природних корінних мішаних ялиново-ялицево-букових лісів, характеризуються недовговічністю і нестійкістю відносно шкідників i хвороб. Вони сприяють виникненню епіфітотій збудників кореневої гнилі - кореневої губки (Fomitopsis annosa) і опенька (Armilla-riellea mellea) в лісових насадженнях регіону, а також катастрофічного розмноження шкідників, зокрема короїда-друкаря (Ips Tepographus L.), короїда багатоходового (Ips amitinus Eichh.), гравера звичайного (Pityogenes chalcographus L.), поліграфа пухнастого (Polygraphus polygraphus L.) (Holubets, 1983).

Розмноженню короїда-друкаря сприяють вітровали, сніголами, посухи, високі температури у період розвитку. Спалахи його чисельності часто стаються й після посушливих років. Високі температури дають йому змогу формувати протягом літа 2-3 генерації розвитку.

Важливим індикатором стану ведення лісового господарства $є$ коренева губка. Її вогнища найчастіше формуються у похідних монокультурах хвойних порід, створених у невластивих для них місцях зростання.

Табл. Стихійні явища в лісах Карпатах, їх взаємодія і причини виникнення

\begin{tabular}{|c|l|c|c|c|c|}
\hline \multirow{2}{*}{$\begin{array}{c}\text { № } \\
3 / п\end{array}$} & \multirow{2}{*}{$\begin{array}{c}\text { Вид стихійних } \\
\text { явищ }\end{array}$} & \begin{tabular}{c} 
Причини виникнення стихійних явищ \\
\cline { 3 - 6 } \\
сивні \\
опади
\end{tabular} & $\begin{array}{c}\text { штормо- } \\
\text { ві вітри }\end{array}$ & засухи & $\begin{array}{c}\text { антропоген- } \\
\text { ний вплив }\end{array}$ \\
\hline 1 & Паводки & ++++ & & & ++ \\
\hline 2 & Селі і зсуви & +++ & & & ++ \\
\hline 3 & Лавини & ++ & & & + \\
\hline 4 & Сніголоми & ++ & + & & ++ \\
\hline 5 & Вітровали & + & ++++ & & + \\
\hline 6 & Вітроломи & + & +++ & & + \\
\hline 7 & Всихання дерев & & + & ++++ & + \\
\hline 8 & Пожежі & & & ++ & ++ \\
\hline 9 & $\begin{array}{l}\text { Масове поши- } \\
\text { рення хвороб }\end{array}$ & & ++ & & +++ \\
\hline 10 & $\begin{array}{l}\text { Масове розмно- } \\
\text { ження шкідників }\end{array}$ & & ++ & + & ++ \\
\hline
\end{tabular}

Примітка: + - частковий вплив $(0,25) ;++-$ опосередкований вплив $(0,5) ;+++-$ значний вплив $(0,75) ;++++-$ основний вплив (1); + - частка впливу кожного із чинників на види і величину стихійного явища.

У природних непорушених ялинових лісах Карпат коренева губка відіграє важливу позитивну роль - разом 3 іншими грибами-деструкторами вона руйнує повалені вітром, ослаблі або перестійні дерева та сприяє пришвидшенню мінералізації органічних речовин. У похідних лісостанах часто формуються спільні вогнища кореневої губки та опенька.

Аналіз особливостей прояву стихійних явищ у гірських екосистемах свідчить про наявність стійких зв'язків між ними (табл.). Так, штормові вітри призводять до вітровалів на значних площах. Оскільки терміни розроблення вітровальних ділянок займають певний час, то розпочинається розмноження шкідників і хвороб. До того ж розвиток патологічних процесів часто набуває катастрофічного характеру. По межі із поваленим лісом ціла смуга дерев 3 підірваною кореневою системою починає всихати. Цей негативний процес поступово наростає, охоплюючи дедалі більшу територію.

Всихання поширюється не тільки на вітровальні площі, але іноді й у здорових насадженнях. Головними факторами виникнення стихійних явищ у лісових насадженнях Карпат $є$ переважно опади, штормові вітри і посухи (рис. 1). Вони створюють умови для виникнення вітровалів, вітроломів, паводків, сніголамів, селів, снігових лавин, зсувів, а також для всихання дерев та виникнення лісових пожеж.

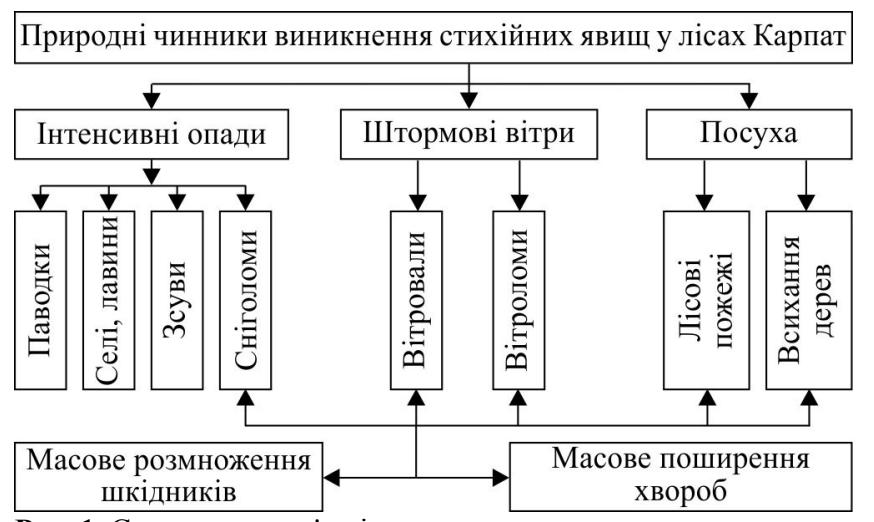

Рис. 1. Схема взаємозв'язків та взаємовпливу природних чинників на виникнення стихійних явищ

Окрім основних чинників формування шкідливих явищ у лісових екосистемах є природні та антропогенні чинники, які можуть підсилювати або сповільнювати стихійні процеси. До них належать структура рослинного покриву, яка безпосередньо залежить від господарської діяльності. Матеріали численних досліджень цієї проблеми свідчать, що лісова рослинність змінюється залежно від висотного положення території н.р.м. та експозиції схилів.

На підставі цього можна стверджувати, що в групі таких чинників, як рельєф місцевості, лісова рослинність і грунти, незалежним є тільки рельєф місцевості.

\section{ЧИННИКИ ВПЛИВУ НА СТИХІЙНІ ЯВИЩА В КАРПАТАХ}

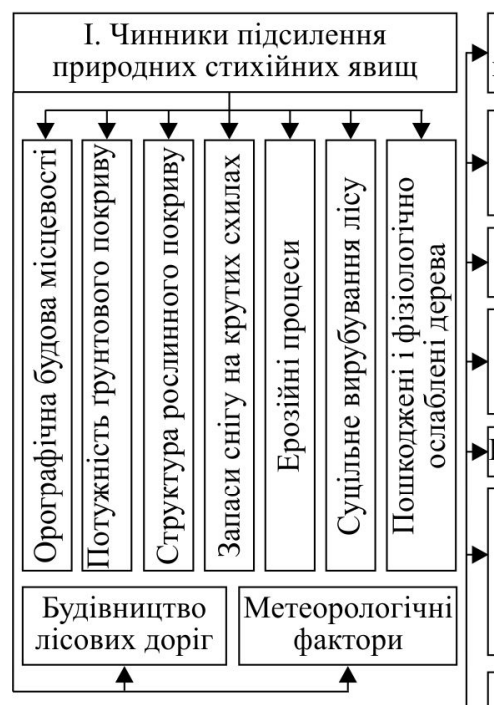

II. Чинники сповільнення природних стихійних явищ

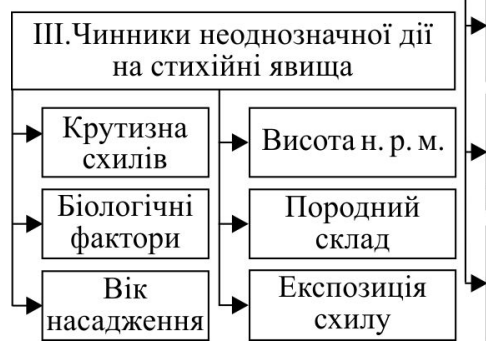

Природозберігальне удосконаленя технології рубоклісу

Збільшення лісистості водозборів

Створення змішаних, різновікових, стійких насаджень Належна селекційна робота Недопущення нагромадження не розробленої вітровальної або всохлої деревини в насадженнях

Своєчасна та ефективна боротьба із шкідниками i хворобами лісу

Планування проведення лісогосподарських заходів за водозбірним принципом

Упровадження екологозберігальних технологій та оптимізація лісових доріг

Рис. 2. Схема взаємодії чинників щодо виникнення, підсилення та стабілізації стихійних явищ у Карпатах 
Процеси формування грунтових умов підпорядковані орографічним елементам - висоті н.р.м., експозиції та крутизні схилів. Своєю чергою грунти впливають на продуктивність деревостанів. Орографія також відіграє істотну роль у розподілі опадів. Вона значно позначається на атмосферній циркуляції у нижній частині тропосфери, зокрема до висоти 1500 м. Напрямок вологоносних повітряних течій і розподіл зволоження дуже залежить від орієнтації хребтів, їх відкритості повітряним течіям або ж захищеності від них іншими хребтами.

Значної шкоди завдають лісовій рослинності та лісовим грунтам снігові лавини. Нагромадження запасів снігу на крутосхилах унаслідок переносу вітрами снігу на значні віддалі призводить під час відлиг до сходження снігових лавин, яким може протистояти відповідного складу рослинний покрив, високогір'я і середньогір'я. Часто повторюючись та взаємодіючи з навколишнім середовищем і між собою, стихійні явища завдають значної шкоди лісовим насадженням Карпат знижуючи продуктивність і їх стійкість, руйнуючи біогеоценоз.

Рис. 2 ілюструє взаємодію чинників різної дії на стихійні явища у лісах Карпат. Впливаючи на чинники, що уповільнюють стихійні явища (II), можна покращити стійкість насаджень. Разом 3 тим, допускаючи збільшення ролі підсилювальних чинників (I) у формуванні стихійних явищ, слід очікувати їх інтенсифікацію і збільшення збитків від них. Певний вплив на величину шкоди від стихійних явищ мають і чинники неоднозначної дії (III). Їх потрібно враховувати під час проведення лісогосподарських заходів, оскільки нехтування ними може посилити процеси формування стихії та нанесені нею збитки.

Висновки. Зменшення збитків від стихійних явищ, які час від часу проявляються, негативно впливають на гірсько-лісові біогеоценози, знижуючи при цьому їх продуктивність та стійкість проти шкідників і хвороб. Враховуючи, що природна реабілітація пошкоджених лісових насаджень це довготривалий процес, через створення лісових культур та лісовирощування у складних гірських умовах вимагають значних витрат. Тому важливим $\epsilon$ використання низки чинників, які сповільнюють негативну дію стихійних явищ, посилюють стійкість і підвищують продуктивність лісових насаджень. У цьому сенсі досить важливі такі заходи:

1. Уникати під час рубань лісу травмування дерев шляхом удосконалення природозберігальних технологій лісозаготівель.

2. Створювати різновікові мішані насадження з бука, ялиці та ялини, як найбільш вітровалостійкі і продуктивні.

3. Застосовувати рубки переформування у похідних ялинниках, створюючи необхідну різновіковість насаджень і вертикальну ступеневу структуру мішаних деревостанів, для підвищення їх стійкості.

4. Замість суцільнолісосічних рубань ширше використовувати поступові і вибіркові способів рубань, не допускаючи зменшення лісистості водозборів. Під час планування лісогосподарських заходів потрібно враховувати стан лісистості і розвиток стихійних явищ на конкретних водозборах.

5. Уникати нагромадження вітровальної або всохлої деревини в лісі, для запобігання небезпеці виникнення пожеж та розмноження шкідників і хвороб.

6. Оптимізувати мережу лісових доріг і створювати стійкі вітроударні узлісся для сповільнення сили вітру і підвищення вітростійкості насаджень.
7. Проводити своєчасну та ефективну боротьбу із шкідниками і хворобами лісу.

8. Здійснювати лісовідновлення вітростійкими аборигенними породами.

Загалом основними напрямами ведення лісового господарства має бути підтримання лісистості території на оптимальному рівні, збереження біологічного різноманіття лісових екосистем, підвищення стійкості їх до негативних чинників середовища та застосування природоощадних способів лісоексплуатації.

\section{Перелік використаних джерел}

Bibliuk, N. I., Kovalchuk, I. P., \& Machuha, O. S. (2008). Hazardous natural phenomena in the Carpathians: causes of occurrence and ways of their minimization. [Nebezpechni stykhiini yavyshcha $v$ Karpatakh: prychyny vynyknennia ta shliakhy yikh minimizatsii]. Zbirnyk Prats. Naukovi pratsi Lisivnychoii akademii nauk, 6, 105119. [In Ukrainian].

Debreniuk, Yu. M. (2011). Dipping of fir wood: causes and effects. [Vsykhannia smerekovykh lisiv: prychyny ta naslidky]. Scientific Bulletin of UNFU, 21(16), 32-38. [In Ukrainian].

Gerushynskij, Z. Yu. (1995). New technology for creating wind-proof cultures in the Carpathians. [Novaja tehnologija sozdanija vetroustojchevyh kultur eli v Karpatah]. Referativnaja informacija, 7, 11-12. [In Russian].

Hensiruk, S. A. (1964). Forests of the Ukrainian Carpathians and their use. [Lisy Ukrainskykh Karpat i yikh vykorystannia]. Kyiv: Urozhai. [In Ukrainian].

Hensiruk, S. A. (1971). Integrated forestry in mountainous conditions. [Kompleksnoe lesnoe khoziaistvo v gornykh usloviiakh]. Moscow: Lesnaia promyshlennost. [In Russian].

Holubets, M. A. (1978). Fir forests of the Ukrainian Carpathians. [Elniki Ukrainskih Karpat]. Kyiv: Nauk. dumka. [In Russian].

Holubets, M. A., Borsuk, D. V., \& Havryliuk, M. V. (1983). Biocenotic cover of Beskydy and its dynamic trends. [Biocenoticheskij pokrov Beskid $i$ ego dinamicheskie tendencii]. Kyiv: Nauk. dumka. [In Russian].

Holubets, M. A., Stoiko, S. M., \& Milkina, L. I. (1993). Nature of the Carpathian National Park. [Pryroda Karpatskoho natsionalnoho parku]. Kyiv: Nauk. dumka. [In Ukrainian].

Isachenko, S. (2014). The Carpathians lose the fir tree. [Karpaty vtrachaiut yalynu]. Retrieved from: http://www.fleg.org.ua/konkurs-2014/292. [In Ukrainian].

Ivaniuk, A. P. (1996). The nature of deadfalls and their impact on forest productivity. [Pryroda vitrovaliv ta yikh vplyv na produktyvnist lisu]. Lviv: Manuskrypt. [In Ukrainian].

Kiriljuk, M. I. (1985). Water balance. [Vodnij balans]. Teplovoi $i$ vodnyj rezhym Ukrainskikh Karpat. Lviv: Gidrometeoizdat. 202218. [In Russian].

Kisilevskyi-Babinin, R. H., \& Diakov, V. M. (1968). The nature of deadfalls in the Carpathians. [Pryroda vitrovaliv u Karpatakh]. Zbirnyk. Pryrodni umovy ta pryrodni resursy Ukraiinskykh Karpat. Kyiv: Nauk. dumka. [In Russian].

Oliinyk, V. S. (2000). Methodological properties of the study and evaluation of the hydrological role of the Carpathian mountain forests. [Metodychni vlastyvosti vyvchennia i otsinky hidrolohichnoi roli hirskykh lisiv Karpat]. Naukovyi visnyk NAU, 25, 159-166. [In Ukrainian].

Oliinyk, V. S. (2013). Hydrological role of forests of the Ukrainian Carpathians. [Hidrolohichna rol lisiv Ukrainskykh Karpat]. IvanoFrankivsk: NAIR. [In Ukrainian].

Perekhrest, S. M., Kochubei S. H., \& Piechkovska O. M. (1971). Harmful phenomena in the Ukrainian Carpathians and means of combating them. [Shkidlyvi stykhiini yavyshcha v Ukrainskykh Karpatakh ta zasoby borotby z nymy]. Kyiv: Nauk. dumka. [In Urkainian]

Prokh, L. Z. (1972). Synoptic conditions of strong winds in the Ukrainian Carpathians. [Sinopticheskie uslovija silnyh vetrov $\mathrm{v}$ Ukrainskih Karpatah]. Trudy UkrNYYHMY, 117. [In Russian]. 
Prokh, L. Z. (1974). Storms in the Carpathians. [Buri v Karpatakh]. Raiduha, 7.

Samoplavskyi, V. I. (2002). Forestry of Ukraine at the beginning of the third millennium. [Lisove hospodarstvo Ukrainy na pochatku tretoho tysiacholittia]. Naukovi pratsi LANU, 1, 6-10. [In Ukrainian].

Прикарпатский национальный университет им. Василия Стефаника, г. Ивано-Франковск, Украина

ВЗАИМОСВЯЗЬ И ВЗАИМООБУСЛОВЛЕННОСТЬ ПРОЯВЛЕНИЯ СТИХИЙНЫХ ЯВЛЕНИЙ В ГОРНО-ЛЕСНЫХ ЭКОСИСТЕМАХ

Рассмотрены взаимосвязи и взаимовлияния между стихийными явлениями в горно-лесных экосистемах Карпат - паводками, эрозией почвы, селями, оползнями, буреломами, снеголомом, схождением снежных лавин, периодическими засухами, лесными пожарами и другими. Приведен перечень стихийных явлений, которые, взаимодействуя между собой, усиливают отдельные из них, замедляя тем самым другие. Выяснено, что в результате антропогенных изменений лесных формаций интенсифицировались вредные процессы, снизилась производительность и стойкость лесных насаждений. Проанализированы причины возникновения отдельных видов стихийных явлений, их влияние на лесные насаждения в настоящее время и в перспективный период. Отмечена значительная вредность для лесного хозяйства перманентных буреломов. Указано на убыточность для лесных экосистем катастрофического снеголома и снеговала, которые деформируют древесину, снижают ее прирост по высоте и запасу и являются очагами возникновения грибных заболеваний. Отмечено, что в местах стихийных явлений растет опасность лесных пожаров, снижается эстетическая и рекреационная ценность лесных ландшафтов. Приведен перечень мероприятий, которые ослабляют действие негативных природных стихийных явлений и повышают стойкость лесных экосистем к антропогенным воздействиям. Важным есть утверждение, что ветроустойчивость насаждений зависит от их породного состава. Наиболее ветроустойчивыми являются насаждения с участием пихты белой и лиственных пород.

Ключевые слова: насаждение; буреломы; паводки; лавины; снеголом; сели; грибные заболевания.

A. Yu. Rak

Vasyl Stefanyk Precarpathian National University, Ivano-Frankivsk, Ukraine

\section{INTERRELATION AND INTERCONDITIONALITY OF THE EMERGENCE OF NATURAL PHENOMENA IN MOUNTAIN-FOREST ECOSYSTEMS}

The problem of sustainability of forest plantations is one of the most topical in forestry. It depends on many reasons, among which climatic, anthropogenic and edaphic factors are determinative ones. Frequent natural phenomena that reduce the stability and productivity of ecosystems in general have significant negative influence on the size of the forest natural resource potential of the Carpathian region. Natural phenomena in the mountain-forest ecosystems of the Carpathians (floods, soil erosion, mudflows, landslides, winds, avalanches, periodic droughts, and forest fires) appear as a result of tension in ecosystems due to the impact of a number of natural and anthropogenic factors on them, causing the violation of complex interconnection bonds and atypical geophysical processes. Among various, different by the source factors, causing such natural phenomena, one can always distinguish between conductive and derivative. They also interact with each other, that is, they amplify some of them, thereby slowing down the others. In areas of natural phenomena losses to forest ecosystems are catastrophic (deformation of wood, reducing its growth in height and stock, the emergence of fungal diseases, increasing the danger of forest fires, reducing the aesthetic and recreational value of forest landscapes). Natural rehabilitation of damaged forest plantations is a long-term process. The development of forest cultures and forestry in difficult mountain conditions require significant costs, therefore, it is important to use a number of factors that slow down the negative effects of natural phenomena, increase the stability and increase the productivity of forest plantations (improvement of environmentally friendly technologies of logging, creation of mixed-aged mixed plantations and their vertical step structure, optimization of the network of forest roads, implementation of reforestation with wind resistant aboriginal rocks). In general, the main areas of forest management should be maintaining the forest area at an optimal level, preserving the biodiversity of forest ecosystems, increasing their resistance to negative environmental factors and applying the nature-saving methods of forest exploitation.

Keywords: plantation; windfalls; floods; avalanches; snowfalls; mudflows; fungal diseases. 